\title{
Chromosome Numbers in Gymnosperms - An Update
}

\author{
Shubhi Rastogi and Deepak Ohri
}

Amity Institute of Biotechnology, Research Cell, Amity University Uttar Pradesh, Lucknow Campus, Malhaur (Near Railway Station), P.O. Chinhat, Luc know-226028 (U.P.)

*Corresponding author: Deepak Ohri, E mail: ohri_deepak@rediffmail.com,dohri@lko.amity.edu

\begin{abstract}
The present report is based on a cytological data base on 614 (56.0\%) of the total 1104 recognized species and 82 (90.0\%) of the 88 recognized genera of gymnosperms. Family Cycadaceae and many genera of Zamiaceae show intrageneric uniformity of somatic numbers, the genus Zamia is represented by a range of number from $2 \mathrm{n}=16-28$. Ginkgo, Welwitschia and Gentum show $2 n=24,2 n=42$, and $2 n=44$ respectively. Ephedra shows a range of polyploidy from $2 x-8 x$ based on $n=7$. The family Pinaceae as a whole shows $2 \mathrm{n}=24$ except for Pseudolarix and Pseudotsuga with $2 \mathrm{n}=44$ and $2 \mathrm{n}=26$ respectively. Araucariaceae constantly shows $2 n=26$ while Podocarpaceae has a range of $2 n=18-38$. Sciadopityaceae and Cupressaceae are represented by $2 n=20$ and $2 n=22$ respectively. Taxaceae shows variable numbers of $2 n=24,36$ and 22 . Polyploidy is exceptional being represented by $8.0 \%$ of the taxa studied. B-chromosomes have been studied in 31 taxa while heteromorphic sex chromosomes have been reported in some dioecious taxa.
\end{abstract}

Keywords: gymnosperms, chromosome numbers, polyploidy, B-chromosome, sex chromosomes

\section{Introduction}

Gymnosperms are a small close knit group of seed plants with significantly less species diversity as compared to angiosperms. Nevertheless, they constitute $39 \%$ of world's forests in both the hemispheres (Armenise et al. 2012) and their importance in regulating global carbon cycles, supply of timber, resins, edible nuts and in horticulture cannot be overstated (Zonneveld 2011, Farjon 2018). As a group, however, there is still some controversy with regard to a monophyletic or paraphyletic origin of the gymnosperms (Hill 2005). Recently they have been classified into four subclasses Cycadidae, Ginkgoidae, Gnetidae and Pinidae under the class Equisetopsida (Chase and Reveal 2009) comprising 12 families and 83 genera (Christenhusz et al. 2011) and 88 genera with 1104 recognized species according to the Plant List (www.theplantlist.org). The validity of accepted name of each taxa and the total number of species in each genus has been checked from the Plant List (www.theplantlist.org). The chromosome numbers of 688 taxa arranged according to the recent classification (Christenhusz et al. 2011) have been summarized in Table 1. The cytological data have been obtained from Chromosome Counts Database (CCDB), Index to Plant Chromosome Numbers (IPCN), Mehra (1988), and over 600 original references, listed separately for each genus in the data base.

\section{Chromosome number data}

The present study is based on a very comprehensive chromosome and genome size data base of gymnosperm species, prepared by the authors. The last compilation of chromosome numbers was done some 60 years back (Khoshoo 1961), a large amount of data has accumulated since then resulting in the representation of 82 genera and 688 taxa comprising of 614 species which is well above that of any other plant group. These data representing $56.0 \%$ of the species and $90.0 \%$ of the genera have provided further insight into the cytological information of this important group of plants. All the gymnosperm genera except Columbea, Austrotaxus, Callitropsis, Neocuprosis, Sabina and Margbansonia are represented in Table 1. The range of chromosome numbers is rather narrow from $2 n=14-66$ showing a 5 -fold variation (Table 1, Fig. 1) as compared to angiosperms from $2 \mathrm{n}=4$-ca.640 a 160-fold variation (Johnson et al. 1989). Another significant feature is the occurrence of a constant basic number in most of the individual families. 
Table1

Chromosome numbers in Gymnosperms

\begin{tabular}{|c|c|c|c|}
\hline Sr. No. & Taxon & Total No. of Species & Chromosome Number (No. of taxa Counted) \\
\hline & Subclass I.: Cycadidae & & \\
\hline & Order A: Cycadales & & \\
\hline & Family: Cycadaceae & & \\
\hline \multirow[t]{2}{*}{1.} & Cycas & 92 & $22(31)$ \\
\hline & Family Zamiaceae & & \\
\hline 2. & Dioon & 13 & $18(10)$ \\
\hline 3. & Bowenia & 2 & $18(2)$ \\
\hline 4. & Macrozamia & 39 & $18(15)$ \\
\hline 5. & Lepidozamia & 2 & $18(2)$ \\
\hline 6. & Encephalartos & 68 & 18 (23) $27(1$ plant, E. hildebrandtii)) \\
\hline 7. & Stangeria & 1 & $16(1)$ \\
\hline 8. & Ceratozamia & 25 & $16(13)$ \\
\hline 9. & Microcycas & 1 & $26(1)$ \\
\hline \multirow[t]{3}{*}{10.} & Zamia & 65 & $16-28(41)$ \\
\hline & Order B: Ginkgoales & & \\
\hline & Family: Ginkgoaceae & & \\
\hline \multirow[t]{4}{*}{11.} & Ginkgo & 1 & 12 (haploid), 24, 36, 48 (1) \\
\hline & SUBCLASS III. GNETIDAE & & \\
\hline & ORDER C. WELWITSCHIALES & & \\
\hline & FAMILY WELWITSCHIACEAE & & \\
\hline \multirow[t]{3}{*}{12.} & Welwitschia & 1 & $42(1)$ \\
\hline & ORDER D. GNETALES & & \\
\hline & FAMILY GNETACEAE & & \\
\hline \multirow[t]{3}{*}{13.} & Gnetum & 41 & $44(3), 44,48(1)$ \\
\hline & ORDER E. EPHEDRALES & & \\
\hline & FAMILY EPHEDRACEAE & & \\
\hline \multirow[t]{4}{*}{14.} & Ephedra & 70 & $14(16), 28(18), 42(2), 42,56(1), 28,56(1), 56(1), 14,28(8), 1$ with Bs \\
\hline & SUBCLASS IV. PINIDAE & & \\
\hline & ORDER F. PINALES & & \\
\hline & FAMILY PINACEAE & & \\
\hline 15. & Cedrus & 3 & $24(4)$ \\
\hline 16. & Pinus & 130 & 24 (103), 36, 48 (1 sporadic), 48 (2 sporadic), 1 with B \\
\hline 17. & Cathaya & 1 & $24(1)$ \\
\hline 18. & Picea & 40 & 24 (37), 36, 48 (2 sporadic), 19 with Bs \\
\hline 19. & Pseudotsuga & 4 & $24(4), 26(2)$ \\
\hline 20. & Larix & 14 & $\begin{array}{l}24 \text { (17), } 36 \text { (1 sporadic), } 48 \text { (1 sporadic), } \\
1 \text { with B }\end{array}$ \\
\hline 21. & Pseudolarix & 1 & $44(1)$ \\
\hline 22. & Tsuga & 10 & $24(10)$ \\
\hline 23. & Nothotsuga & 1 & $24(1)$ \\
\hline 24. & Keteleeria & 3 & $24(4)$ \\
\hline \multirow[t]{3}{*}{25.} & Abies & 48 & 24 (33), 48 (1 sporadic), 36, 48 (1 sporadic) \\
\hline & Order: Araucariales & & \\
\hline & Family 8: Araucariaceae & & \\
\hline 26. & Araucaria & 19 & $26(20)$ \\
\hline 27. & Wollemia & 1 & $26(1)$ \\
\hline 28. & Agathis & 18 & $26(3)$ \\
\hline \multirow[t]{2}{*}{29.} & Columbea & 1 & -- \\
\hline & Family9: Podocarpaceae & & \\
\hline 30. & Phyllocladus & 4 & $18(4)$ \\
\hline 31. & Lepidothamnus & 4 & $28(1), 30(2)$ \\
\hline 32. & Prumnopitys & 9 & $36(1), 38(2)$ \\
\hline 33. & Sundacarpus & 1 & $38(1)$ \\
\hline 34. & Halocarpus & 3 & $18(1), 22(1), 24(1)$ \\
\hline 35. & Parasitaxus & 1 & $36(1)$ \\
\hline 36. & Lagarostrobos & 1 & $30(1)$ \\
\hline 37. & Manoao & 1 & $20(1)$ \\
\hline 38. & Saxegothaea & 1 & $24(1)$ \\
\hline
\end{tabular}


Table 1: continued

\begin{tabular}{|c|c|c|c|}
\hline Sr. No. & Taxon & Total No. of Species & Chromosome Number (No. of taxa Counted) \\
\hline 39. & Microcachrys & 1 & $30(1)$ \\
\hline 40. & Pherosphaera & 2 & $26(2)$ \\
\hline 41. & Acmopyle & 2 & $20(2)$ \\
\hline 42. & Dacrycarpus & 9 & $20(3)$ \\
\hline 43. & Dacrydium & 22 & $20(9)$ \\
\hline 44. & Falcatifolium & 6 & $20(1)$ \\
\hline 45. & Retrophyllum & 5 & $20(3)$ \\
\hline 46. & Nageia & 6 & $26(2), 26,20(1)$ \\
\hline 47. & Afrocarpus & 5 & $24(3)$ \\
\hline 48. & Podocarpus & 108 & $\begin{array}{l}22(1), 33(1), 34(2), 36(1), 38(3), 20,22(2), 34,36(1), 34,35,36(1), \\
33,34,38(1), 37,38(2)\end{array}$ \\
\hline \multirow[t]{3}{*}{49.} & Margbensonia & 1 & --- \\
\hline & ORDER H. CUPRESSALES & & \\
\hline & FAMILY 10. SCIADOPITYACEAE & & \\
\hline \multirow[t]{2}{*}{50.} & Sciadopitys & 1 & $20(1)$ \\
\hline & FAMILY 11. CUPRESSACEAE & & \\
\hline 51. & Cunninghamia & 2 & 22 (2), 33 (1 sporadic), 1 with B's \\
\hline 52. & Taiwania & 1 & $22(1), 33$ (1 sporadic), 1 with B's \\
\hline 53. & Athrotaxis & 3 & $22(3)$ \\
\hline 54. & Metasequoia & 2 & 22 (1), 1 with Bs \\
\hline 55. & Sequoia & 1 & 66 (1), 1 with Bs \\
\hline 56. & Sequoiadendron & 1 & $22(1)$ \\
\hline 57. & Cryptomeria & 1 & 22 (1), 33 (1 sporadic), \\
\hline 58. & Glyptostrobus & 1 & $22(1), 33$ (1 sporadic) \\
\hline 59. & Taxodium & 2 & 22 (3), 1 with Bs \\
\hline 60. & Papuacedrus & 1 & $22(1)$ \\
\hline 61. & Austrocedrus & 1 & $22(1)$ \\
\hline 62. & Libocedrus & 5 & $22(1)$ \\
\hline 63. & Pilgerodendron & 1 & $22(1)$ \\
\hline 64. & Widdringtonia & 4 & $22(4)$ \\
\hline 65 & Diselma & 1 & $22(1)$ \\
\hline 66. & Fitzroya & 1 & $44(1)$ \\
\hline 67. & Callitris & 15 & $22(6)$ \\
\hline 68. & Actinostrobus & 3 & $22(1)$ \\
\hline 69. & Neocallitropsis & 1 & $22(1)$ \\
\hline 70. & Thujopsis & 1 & $22(1)$ \\
\hline 71. & Thuja & 5 & $22(5)$ \\
\hline 72. & Fokienia & 1 & $22(1)$ \\
\hline 73. & Chamaecyparis & 5 & $22(7)$ \\
\hline 74. & Cupressus & 19 & $22(22), 22,44(2), 44$ (1), 4 with B's \\
\hline 75. & Juniperus & 75 & $\begin{array}{l}22(71), 22,33(1), 33,44(1), 22,33,44(1), 22,44(7), 44(9), 22,44,66 \\
(1), 22,66(1)\end{array}$ \\
\hline 76. & Calocedrus & 4 & $22(3)$ \\
\hline 77. & Tetraclinis & 1 & $22(1)$ \\
\hline 78. & Platycladus & 1 & $22(1) 33,44$ (Sporadic) \\
\hline 79. & Microbiota & 1 & $22(1)$ \\
\hline 80. & Callitropsis & 1 & --- \\
\hline 81. & Neocuprosis & 3 & --- \\
\hline \multirow[t]{2}{*}{82.} & Sabina & 2 & --- \\
\hline & Family 12: Taxaceae & & \\
\hline 83. & Pseudotaxus & 1 & $24(1)$ \\
\hline 84. & Taxus & 9 & $24(10), 16(1), 1$ withBs \\
\hline 85. & Cephalotaxus & 8 & $24(6)$ \\
\hline 86. & Amentotaxus & 6 & $36(1), 14,40,36(1)$ \\
\hline 87. & Torreya & 6 & $22(4)$ \\
\hline 88. & Austrotaxus & 1 & --- \\
\hline
\end{tabular}




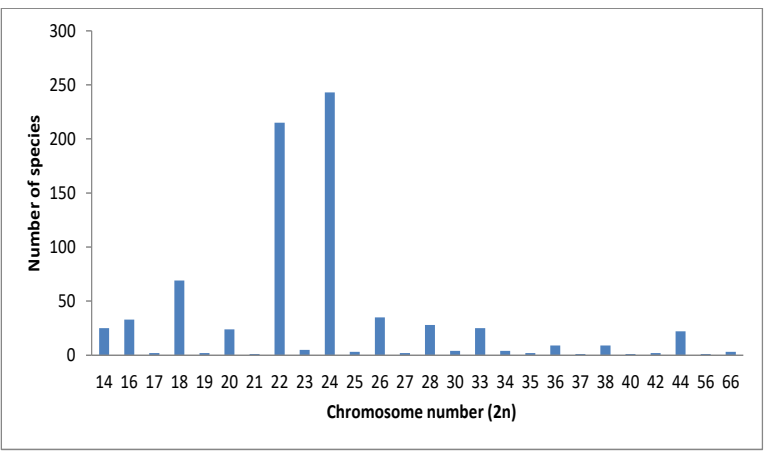

Fig. 1

Distribution of $2 \mathrm{n}$ chromosome numbers in 688 taxa of gymnosperms

Cycadaceae: Out of the total of 92 species, 31 species of Cycas studied show $2 \mathrm{n}=22$ (Table 1 ).

Zamiaceae: This family with nine genera shows variable chromosome numbers. The cytologically studied species of Dioon (10 spp.), Bowenia (2 spp.), Macrozamia (15 spp.), Lepidozamia (2spp.), Encephalartos (23 spp.) have $2 \mathrm{n}=18$, Stangeria (1 sp.), Ceratozamia (13 spp.) have $2 n=16$ while Microcycas shows $2 n=26$ (Table 1). However, Zamia with 41 species studied shows a dysploid range from $2 \mathrm{n}=16-28$ while $Z$. chigua $(2 n=22,24,25,26$; Norstog 1980, 1981), Z. herrerae $(2 n=23,24$; Nicolalde-Morejon et al.2009), Z. lacandona $(2 n=16,17,18$; Schutzman \& Vovides 1998), Z. loddigesii ( $2 n=17,18$ 24-27; Moretti \& Sabato 1984, Moretti 1990, Tagashira \& Kondo 1999, 2001, Vovides \& Olivares 1996), Z. paucizuga $(2 n=19,23,25,27$, 28; Napalitano et al. 2004), Z. prasina $(2 n=22,26$; Moretti et al. 1993) and Z. variegata ( $2 n=21,22$; Moretti et al. 1991, 1993) show extensive intraspecific variation (Table 1 ). All this variability in chromosome numbers without any change in the number of chromosome arms is however, explained by centric fissions as there exists a ratio of one-to-two between median and terminal chromosomes with increase or decrease of somatic number (Olson \& Gorelick 2011, Rastogi \& Ohri 2019).

Ginkgoaceae: This monotypic family with Ginkgo biloba has $2 \mathrm{n}=24$ (Table 1 ).

Welwitschiaceae: The only species Welwitschia mirabilis with $2 n=42$ has a unique all telocentric karyotype (Khoshoo and Ahuja 1963).

Gnetaceae: Four species of Gnetum i.e., Gnetum gnemon, Gnetum montanum, Gnetum ula and Gnetum costatum show $2 \mathrm{n}=44$ (Table 1).

Ephedraceae: Ephedra shows a range of somatic numbers from $2 n=14-56$ among 47 species studied. The ploidy level goes up to octoploidy which is the highest among gymnosperms (Table 1).

Pinaceae: Among 11 genera included in this family Cedrus, Pinus, Cathaya, Picea, Psudotsuga (except P. menziesii), Larix, Tsuga, Nothotsuga, Keteleeria and Abies constantly show $2 \mathrm{n}=24$. Pseudotsuga menziesii shows a dysploid variation of $2 n=26$ and Pseudolarix amabilis has $2 n=44$. P. menziesii has a different karyotype of $10 m+12 s m+4 t$ while $2 n=24$ species lack smaller telocentrics and instead have an additional metacentric pair which shows that increase in number is due to centric fission in a metacentric pair (Christiansen 1963, El-Kassaby et al. 1983, Hizume \& Kondo 1992, Hizume \& Akiyama 1992). The CMA banding pattern of $P$. menziesii however, does not allow any derivation from $2 \mathrm{n}=24$ species studied by Hizume \& Kondo (1992). Similarly, Pseudolarix amabilis which shows 4 long submetacentrics and 40 small telocentrics of gradually decreasing size, derives its karyotype by centric fission of 20 sub-metacentrics (Mergen 1961, Hizume 2015).

Araucariaceae: Three genera investigated i.e. Araucaria, Agathis and Wollemia uniformly have $2 \mathrm{n}=26$ (Table 1 ). There is no report for Columbea.

Podocarpaceae: Chromosome numbers of 19 species have been studied except for Margbensonia (Table 1). A variation of $2 n=18-38$ occurs in 19 genera and the karyotypes are characterized by various combinations of meta-, acro- and telocentric chromosomes resulting from centric fission (Table 1) (Hair and Beuzenberg 1958, Davies et al. 1997).

Sciadopityaceae: This monotypic family with Sciadopitys verticillata has a highly symmetrical complement of $2 n=20$ (Hizume 1989) (Table 1).

Cupressaceae: This family comprises 32 genera and except for Callitropsis, Neocuprosis and Sabina which have not been investigated, the rest have constant basic number of $x=11$ (Table 1). Out of the 169 species studied 144 are diploid with $2 n=22$, intraspecific polyploidy is shown by 13 species and 12 species are exclusively polyploid (Table 1 ).

Taxaceae: Variable numbers are present i.e., $2 \mathrm{n}=24$ (Taxus and Cephalotaxus), $2 n=40,36,14$ (Amentotaxus) and $2 n=22$ (Torreya) (Table1). The report in Amentotaxus however, needs further verification. The only remaining genus is Austrotaxus which has not been investigated.

\section{Polyploidy}

As has been explained earlier, the cases of recent polyploidy are very less and exceptional in comparison to angiosperms (Khoshoo 1959, Ahuja 2005). The data obtained till now shows that out of 685 taxa known cytologically 5.0 per cent are polyploid 3.0 per cent have both diploid and polyploid types and the rest 92.0 per cent are diploid (Fig. 2). Ployploidy in the gymnosperms occurs in the form of stray seedlings, individual trees, intraspecific polyploidy in cultivation or in wild and entirely polyploid species and genera (Khoshoo1959).

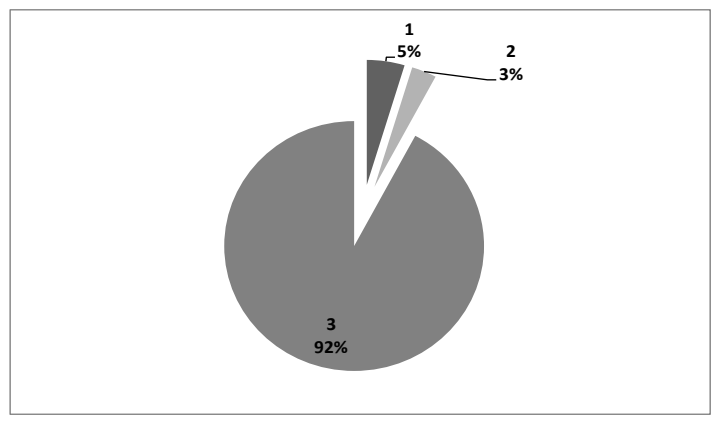

Fig. 2

Percentage of polyploids (1), intraspecific polyploids (2) and diploids (3) in 685 taxa of gymnosperms 
In the entire Cycadidae a single case of a triploid individual is known in a cycad species Encephalartos hildebrandtii (Abraham and Mathew 1966).

Individual cases of polyploidy have been found in some Pinaceae i.e. Pinus, Picea, Larix, Abies and Cupressaceae genera i.e. Cunninghamia, Taiwania, Cryptomeria, Glyptostrobus, Cupressus, Juniperus and Platycladus (Table 1 ).

Recently an extensive survey of 2200 individual trees which included seedlings obtained from a known tetraploid tree (Smarda et al. 2018) and 371 plants of 200 cultivars has shown a spontaneous origin of haploid, triploid and tetraploid individuals and named cultivars (Table 1), morphologically distinct from diploids, growing in semi-natural and cultivated state (Smarda et al. 2018). It is therefore stated that Ginkgo biloba spontaneously produces individuals at different ploidy levels in a frequency which is well above being sporadic or extremely rare, however these polyploid individuals while grow normally in cultivation, supposedly have low survival in wild (Smarda et al. 2018).

Ephedraceae and Cupressaceae have been recently found to have a high incidence of polyploidy than the cases earlier known. In Ephedraceae out of the total of 47 species studied, intraspecific polyploidy is detected in Ephedra americana, $E$. chilensis, E.equisetina, E. fragilis, E.gerardiana, E. monosperms, $E$ przewalskii, E. regeliana (2x,4x), and exclusively polyploid species are E. altissima, E. aspera, E. boelckei, E. coryi, E. culteri, E. distachya, E. distachya subsp. helvetica, E. gerardiana var. sikkimensis, E. glauca, E. likiangensis, E. likiangensisf. mairei, E. lomatolepis, E. nevadensis, E. sinica, E. strobilacea, E. transitoria, E trifurca, $E$. viridis (4x), E. californica $(6 \mathrm{x}, 8 \mathrm{x})$, E. funerea $(4 \mathrm{x}, 8 \mathrm{x})$, E. aphylla, $E$. sarcocarpa (6x), E. antisyphilitica (8x) (Ickert Bond et al. 2014, Wu et al. 2016).

Similarly in Cupressaceae out of 169 species studied 13 show intraspecific polyploidy i.e. Cupressus dupreziana, C. macrocarpa $(2 x, 4 x)$, Juniperus chinensis $(2 x, 3 x, 4 x)$, J. chinensis var. sargentii, J. deppeana var. gamboana, J. pingii, J. polycarpos var. seravschanica, J. sabina, J. squamata, J. squamata f. wilsonii $(2 \mathrm{x}$, $4 x)$, J. foetidissima $(2 x, 6 x)$, J. phoenicea $(2 x, 4 x, 6 x)$ (Table 1). Exclusively polyploid species are Sequoia sempervirens (6x), Fitzroya cupressoides, Cupressus guadalupensis var. forbesii, Juniperus coxii, J. indica, J. procumbens, J. przewalskii, J. recurva, J. sabina var. balkanensis, J. thurifera, J. thurifera subsp. africana, J. tibetica (4x), J. pfitzeriana $(3 \mathrm{x}, 4 \mathrm{x})$ (Table 1). Interestingly, a rather high incidence of polyploidy is observed in Ephedra (64.0\%) (Wu et al. 2016) and Juniperus (21.0\%) (Farhat et al. 2019a, b) (Figs. 3,4).

Autotetraploidy has been deduced in Fitzroya cupressoides based on tetrasomic inheritance (Premoli et al. 2000). The karyotype studies in Sequoia, Metasequoia and Sequoiadendron have brought out distinct differences between the karyotype of Sequoia and that of other genera therefore precluding the derivation of Sequoia complement from that of its close relatives (Schlarbaum and Tsuchiya 1975, 1984a, b, Ahuja 2005, 2009). Meiotic configurations in Sequoia further depict an overwhelmingly large numbers of bivalents and some multivalents including hexavalents indicating a diploidized autohexaploid, autoallohexaploid or a segmental hexaploid genome

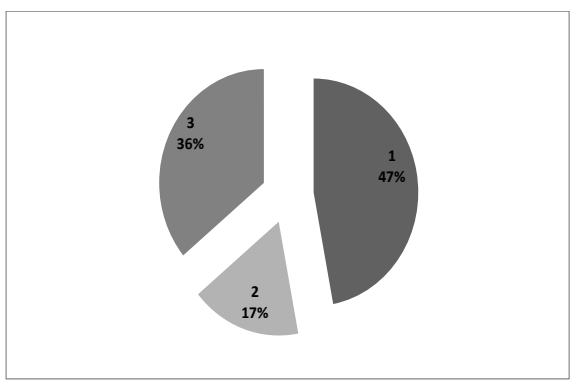

Fig.3

Percentage of polyploids (1), intraspecific polyploids (2) and diploids (3) in 47 taxa of Ephedra

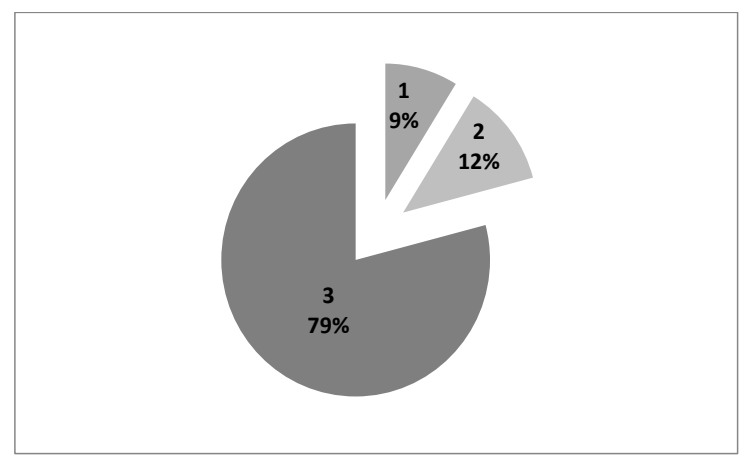

Fig.4

Percentage of polyploids (1), intraspecific polyploids (2) and diploids (3) in 91 taxa of Juniperus

(Ahuja \& Neale 2002, Hizume et al. 2014, Ahuja 2009). Recently transcriptome data followed by Baysian concordance analysis of single-copy genes strongly supported Sequoiadendron rather than Metasequoia as closest relative of Sequoia thereby discounting any genomic contribution from Metasequoia. However, the phylogenetic relationships based on single-copy genes do not exclude hybridization within SequoiadendronSequoia clade therefore further evidence for autopolyploidy was obtained from orthogroups or homeologs of Sequoia as the duplicate genes show more similarity of sequences than expected (Scott et al. 2016). On the contrary, the interrelationships based on two single copy nuclear genes (LFY and DDB2) and two chloroplast DNA fragments reveal widespread interspecific hybridization followed by allotetraploidy in Ephedra species (Wu et al. 2016). Another exclusively 4x species, Juniperus thurifera shows diploidization of its genome in revealing two 35S rDNA sites similar to diploid species (Valles et al. 2015). Therefore, it is clear that recent cases of polyploidy are primarily seen in Cupressaceae and Ephedraceae and the present data shows that total incidence of polyploidy in gymnosperms is about $8.0 \%$.

\section{B-chromosomes}

Like polyploidy, B-chromosomes also occur in very low frequency as compared to angiosperms. Supernumerary chromosomes have been detected in 31 taxa which make up about 5 
$\%$ of the total cytologicaly known taxa. Solitary cases are present in Ephedra, Pinus, Podocarpus, Taxus, Cunninghamia and Pseudotsuga. However, a tree with $2 \mathrm{n}=27$ in Pseudotsuga menziesii may well be a trisomic (Owens 1967). Larix and Cupressus show B-chromosomes in two and three taxa respectively. The greatest frequency of instances are seen in Picea where 18 taxa show B-chromosomes in varying numbers (Table 1) (Rastogi and Ohri 2019).

\section{Sex chromosomes}

Majority of the gymnosperm species (64.6\%) are dioecious represented by Cycadidae, Gnetidae, Ginkgo and some species in Pinidae and the rest are hermaphrodite monoecious (Ohri \& Rastogi 2019). Therefore, in dioecious taxa many studies have tried to show sex determination based on heteromorphism of sex chromosomes where either heteromorphic sex is male with XX/XY or female with ZZ/WZ system. In Podocarpus the male sex chromosome may even be formed by the fusion of two telocentrics giving rise to $\mathrm{X}_{1} \mathrm{X}_{2} \mathrm{X}_{1} \mathrm{X}_{2} / \mathrm{X}_{1} \mathrm{X}_{2} \mathrm{Y}$ system. Some species of Cycas, Zamia, Stangeria and one each of Ephedra, Podocarpus and Ginkgo show heteromorphic sex chromosomes (Table 1). These studies nevertheless, require further detailed analyses and confirmation (Ohri and Rastogi 2019).

\section{Conclusions}

As a small group, gymnosperms are well represented for their chromosome numbers compared with angiosperms. The dysploid variation is present in Zamia, Pseudotsuga, Pseudolarix and in Podocarpaceae because of chromosomal fusion/fission which do not alter the chromosome arms but increase/decrease chromosome number. The chromosome numbers and karyotypes are however, conserved within various families. Recent studies have shown that this apparent uniformity of chromosome number and form is not commensurate with great variation in fluorescent bands and number and position of rDNA and other repetitive sequences studied by fluorescent in situ hybridization (FISH) (Rastogi and Ohri 2019, Ohri \& Rastogi unpublished). Such studies need to be extended to species which need further investigation as this will not only facilitate identification of chromosomes in the complement but also help to describe the interrelationships in various taxa. Similarly, as compared to angiosperms, B-chromosomes have been found in a small percentage of species with a non-random distribution, having been mostly discovered in Picea species (Rastogi \& Ohri 2019). This aspect needs further investigation as the adaptive value shown by B-chromosomes in some particular ecological niche as found in some cases, has implications in forestry. Similarly a majority of gymnosperm species are dioecious but heteromorphic sex chromosomes have been discovered in less than one percent of the species. This aspect needs to be further explored in view of the studies done in Dacrycarpus dacrydioides and Manoao colensoi where distinct differences observed in genome size among male and female plants could not be detected in their karyotypes (Ohri \& Rastogi
2019). The present work therefore summarizes the chromosome numbers investigated presently with a view to bring out the gaps in our knowledge of this rather important group of seed plants.

\section{Acknowledgements}

We are grateful to DBT, Govt. of India, New Delhi for financial assistance. Thanks are also due to Pro-ViceChancellor and Dean Science and Technology Amity University Uttar Pradesh, Lucknow Campus for encouragement and support. Data Archiving Statement

\section{References}

Abraham A, Mathews PM (1962) Cytological studies in the cycads: sex chromosomes in Cycas. Annals of Botany 26: 261-266 https://doi.org/10.1093/oxfordjournals.aob.a083792

Ahuja MR (2005) Polyploidy in gymnosperms revisited. Silvae Genetica 54: 5969. https://doi.org/10.1515/sg-2005-0010

Ahuja MR (2009) Genetic constitution and diversity in four narrow endemic redwoods from the family Cupressaceae. Euphytica 165: 5-19 https://doi.org/10.1007/s10681-008-9813-3

Ahuja MR, Neale DB (2002) Origins of polyploidy in coast redwood (Sequoia sempervirens) (D. Don) Endl. and relationship of coast redwood to other genera of Taxodiaceae. Silvae Genetica 51: 93-100.

Armenise L, Simeone M, Piredda R, Schirone B (2012) Validation of DNA barcoding as an efficient tool for taxa identification and detection of species diversity in Italian conifers. Eur. J. Forest Res. 131: 1337-1353. https://doi.org/10.1007/s10342-012-0602-0

Chase MW, Reveal JL (2009) A phylogenetic classification of the land plants to accompany APGIII. Bot. J. Linnean Soc. 161: 122-127. https://doi.org/10.1111/j.1095-8339.2009.01002.x

Christiansen H (1963) On the chromosomes of Pseudotsuga macrocarpa and Pseudotsuga menziesii. Silvae Genetica 12: 124-127.

Christenhusz MJM, Reveal JL, Farjon A, Gardner MF, Mill RR, Chase MW (2011) A new classification and linear sequence of extant gymnosperms. Phytotaxa 19: 55-70. https://doi.org/10.11646/phytotaxa.19.1.3

Davies BJ, O'Brien IEW, Murray BG (1997) Karyotypes, chromosome bands and genome size variation in New Zealand endemic gymnosperms. Plant Systematics and Evolution 208: 169-185. https://doi.org/10.1007/bf00985440

El Kaasaby YA, Colangeli AM, Sziklai O (1983) A numerical analysis of karyotypes in the genus Pseudotsuga. Canadian Journal of Botany 61: 536-544. https://doi.org/10.1139/b83-060

Farhat P, Hidalgo O, Robert T, Siljak-Yakovlev S, Leitch I, Adams RP, Daghar Kharrat MB (2019a) Polyploidy in the genus Juniperus: and unexpectedly high rete. Frontiers in Plant Science 10: Article 676 https://doi.org/10.3389/fpls.2019.00676

Farhat P, Siljak-Yakovlev S, Adams RP, Daghar Kharrat MB, Robert T(2019b) Genome size variation and polyploidy in the geographical range of Juniperus sabina L. (Cupressaceae). Botany Letters https://doi.org/10.1080/23818107.2019.1613262

Farjon A (2018) The Kew review: conifers of the world. Kew Bulletin 73: 8 https://doi.org/10.1007/s12225-018-9738-5

Hair JB, Beuzenberg EJ (1958) Chromosomal evolution of the Podocarpaceae. Nature 181: 1584-1586. https://doi.org/10.1038/1811584a0

Hill K (2005) Diversity and evolution of gymnosperms. In: Henry RJ (ed.), Plant Diversity and Evolution: Diversity and Phenotypic Variation in Higher Plants CABI Publishing Wallingford, Oxfordshire UK. https://doi.org/10.1079/9780851999043.0025 
Hizume M (1989) Karyomorphological studies in twelve species in the Taxodiaceae with special reference to cytotaxonomical position of Sciadopitys verticillata. Mem. Fac. Educ. Ehime Univ., Ser. 3, Nat. Sci. 9: 7-32

Hizume M (2015) Fluorescent band patterns of chromosomes in Pseudolarix amabilis, Pinaceae. Cytologia 80: 151-157. https://doi.org/10.1508/cytologia.80.151

Hizume M, Akiyama M (1992) Size variation of chromomycin A3-band in chromosomes of Douglas fir, Pseudotsuga menziesii. Japanese Journal of Genetics 67: 425-435. https://doi.org/10.1266/jjg.67.425

Hizume M, KondoK (1992) Fluorescent chromosome banding in five taxa of Pseudotsuga, Pinaceae. La Kromosomo Il 66: 2257-2268.

Hizume M, Kaneko K, Miyake T (2014) A method for the preparation of meiotic chromosomes of conifers and its applications. Chromosome Botany 9: 8388. https://doi.org/10.3199/iscb.9.83

Ickert Bond SM, Sousa A, Ya M, Pellicer J, Leitch I (2014) The evolution of genome size in gymnosperm genus Ephedra: Flow cytometry and new chromosome counts support high levels of polyploidy. Botany New Frontiers in Botany, The Boise Centre-Boise Idaho July 26-30, 2014.

Johnson MAT, Kenton AY, Bennett MD, Brandham PE (1989) Voanioala gerardii has the highest known chromosome number in monocotyledons. Genome 32: 328-333. https://doi.org/10.1139/g89-449

Khoshoo TN (1959) Polyploidy in gymnosperms. Evolution 13: 24-39 https://doi.org/10.1111/j.1558-5646.1959.tb02991.x

Khoshoo TN (1961) Chromosome numbers in gymnosperms. SilvaeGenetica 10: 1-7

Khoshoo TN, Ahuja MR (1963) The chromosomes and relationships of Welwitschia mirabilis. Chromosoma 14: 522-533. https://doi.org/10.1007/bf00321471

Mehra PN (1988) Indian Conifers, Gnetophytes and Phylogeny of Gymnosperms. Panjab University, Chandigarh

Mergen F (1961) The chromosomes of Pseudolarix amabilis. Cytologia 26: 213 216. https://doi.org/10.1508/cytologia.26.213

Moretti A (1990) Karyotype data on North and Central American Zamiaceae (Cycadales) and their phylogenetic implications. American Journal of Botany 77: 1016-1029. https://doi.org/10.1002/j.1537-2197.1990.tb13597.x

Moretti A, Sabato S (1984) Karyotype evolution by centromeric fission in Zamia (Cycadales). PI. Syst. Evol. 146: 215-223. https://doi.org/10.1007/bf00989547

Moretti A, Caputo P, Gaudio L, Stevenson DW (1991) Intraspecific chromosome variation in Zamia (Zamiaceae, Cycadales). Caryologia 44: 1-10. https://doi.org/10.1080/00087114.1991.10797013

Moretti A, Caputo P, Cozzolino S,Gaudio L (1993) Karyotypes of New World cycads. Pp. 263--270 in D. W. Stevenson \& K. J. Norstog (editors), The Biology, Structure, and Systematics of the Cycadales: Proceedings of Cycad 90, the Second International Conference on Cycad Biology. Palm \& Cycad Societies of Australia, Milton, Queensland.

Napalitano A, Caputo P, Moretti A (2004) Karyology, phytogeography, and the origin of intraspecific karyotype variation in Zamia paucijuga and Z. polymorpha (Zamiaceae). Delpinoa 46: 71-83.

Nicolalde-Morejon F, Vovides AP, Stevenson DW (2009) Taxonomic revision of Zamia in Mega-Mexico. Brittonia, 61:301-335 https://doi.org/10.1007/s12228-009-9077-9

Norstog K (1980) Chromosome numbers in Zamia (Cycadales). Caryologia 33 419-428. https://doi.org/10.1080/00087114.1980.10796855

Norstog K (1981) Karyotypes of Zamia chigna (Cycadales). Caryologia 34: 255 260. https://doi.org/10.1080/00087114.1981.10796889

Ohri D, Rastogi S (2019) Sex determination in cycads. Nucleus. https://doi.org/10.1007/s13237-019-00302-2

Olson K, Gorelick R (2011) Chromosomal fission accounts for small scale radiations in Zamia (Zamiaceae; Cycadales). Botanical Journal of the Linnean Society 165: 168-185. https://doi.org/10.1111/j.1095-8339.2010.01102.x

Owens JN (1967) Chromosme aberration in Douglas fir. Canadian Journal of Botany 45: 1910-1913. https://doi.org/10.1139/b67-207

Premoli AC, Kitzberger T, Veblen TT (2000) Isozyme variation and recent biogeographical history of the long lived conifer Fitzroya cupressoides. J. Biogeogr. 27: 251-260.https://doi.org/10.1046/j.1365-2699.2000.00402.x

Rastogi S, Ohri D (2019) B-chromosomes in gymnosperms. Silvae Genetica 68: 51-54. https://doi.org/10.2478/sg-2019-0009
Rastogi S, Ohri D (2019) Karyotype evolution in Cycads. Nucleus https://doi.org/10.1007/s13237-019-00302-2

Schlarbaum SE, Tsuchiya T (1975) The chromosome study of giant sequoia, Sequoiadendron giganteum. Silvae Genetica 24: 23-26.

Schlarbaum SE, Tsuchiya T (1984a) Cytotaxonomy and phylogeny in certain species of Taxodiaceae. Plant Systematics and Evolution 147: 29-54 https://doi.org/10.1007/bf00984578

Schlarbaum SE, Tsuchiya T (1984b) A chromosome study of coast redwood, Sequoia sempervirens D. (Don) Endl. Silvae Genetica 33: 56-62

Schutzman B, Vovides AP (1998) A new Zamia (Zamiaceae, Cycadales) from eastern Chiapas, Mexico. Novon 8: 441-446. https://doi.org/10.2307/3391871

Scott AD, Stenz NWM, Ingvarsson PK, Baum DA (2016) Whole genome duplication in coast redwood (Sequoia sempervirens) and its implications for explaining the rarity of polyploidy in conifers. New Phytologist 211: 186-193 https://doi.org/10.1111/nph.13930

Smarda P, Horova L, Knapek O, Dieck H, Dieck M, Razna K, Hrubik P, Orloci L, Papp L, Vesela K, Vesely P, Bures P (2018) Multiple haploids triploids and tetraploids found in modern day 'living fossil' Ginkgo biloba. Horticulture Research 5:55. https://doi.org/10.1038/s41438-018-0055-9

Tagashira N, Kondo K (1999) A karyotype comparison of nine species of aneuploid Zamia by using the conventional orcein staining and the fluorochrome CMA-DAPI differential staining methods. Cytologia 64: 449-458. https://doi.org/10.1508/cytologia.64.449

Tagashira N, Kondo K (2001) Chromosome phylogeny of Zamia and Ceratozamia by means of Robertsonian changes detected by fluorescence in situ hybridization (FISH) technique of rDNA. Plant Systematics and Evolution 227:145155. https://doi.org/10.1007/s006060170045

The Plant List 2010. Version 1 Published on the Internet; http://www.theplantlist.org/

Vallès V, Garnatje T, Robin O, Siljak-Yakovlev S (2015) Molecular cytogenetic studies in western Mediterranean Juniperus (Cupressaceae): a constant model of GC-rich chromosomal regions and rDNA loci with evidences for paleopolyploidy. Tree Genetics \& Genomes 11:43 https://doi.org/10.1007/s11295-015-0860-3

Vovides AP, Olivares M (1996) Karyotype polymorphism in the cycad Zamia loddigesii (Zamiaceae) of the Yucatan Peninsula, Mexico. Bot. J. Linn. Soc. 120: 77-83. https://doi.org/10.1111/j.1095-8339.1996.tb00481.x

Wu H, Ma Z, Wang MM, Qin AL, Ran JH,Wang XQ (2016) A high frequency of allopolyploid speciation in the gymnospermous genus Ephedra and its possible association with some biological and ecological features. Molecular Ecology 25: 1192-210. https://doi.org/10.1111/mec.13538

Zonneveld BJM (2011) Pine nut syndrome: a simple test for genome size of 12 pine nut-producing trees links the bitter aftertaste to nuts of $P$. armandii Zucc.exEndl. Plant Systematics and Evolution 297: 201-206 https://doi.org/10.1007/s00606-011-0507-2 